\title{
6. Citizen action and the consolidation of democracy in Nigeria: a study of the 2007 movement
}

\author{
JIBRIN IBRAHIM AND SAMUEL EGWU
}

\section{Introduction}

This chapter is about the struggle to consolidate democratic gains in Nigeria through citizen mobilization, following President Olusegun Obasanjo's attempt to change the constitution in order to prolong his tenure in office for a third term. It examines the mobilization of an anti-third term camp, which was drawn from Nigeria's parliament, civil society, opposition parties and the popular masses. In particular, we will focus closely on the role played by the 2007 Movement, a coalition of parliamentarians who formed the nucleus of the opposition to the tenure extension bid. This fierce battle for the soul of Nigeria's democracy, which was openly fought by pro- and anti-third term groups between January 2005 and May 2006, was resolved when the National Assembly moved to throw out the Constitutional Amendment Bill, which (if passed) would have made Obasanjo's tenure extension a reality. ${ }^{1}$

This chapter is also about disagreements over the meaning of democracy. President Obasanjo had one definition of what constitutes democracy, which can be seen from the way members of his entourage normally introduced him on public occasions - as the 'founder of modern Nigeria', with a 'divine'2 will to combat corruption, streamline state institutions, introduce due process into economic governance, and send the country along the path of rapid economic development. So important was this mission to the president and his team that they believed themselves justified in using all possible mediating powers of the state to change the rules, so that they could continue in office. To them, democracy meant 'good governance', in the narrow sense of promoting accountability and due process. As such, they did not hesitate to participate in massive vote rigging in the 2003 and 2007 elections, so that the 'good governance' team could continue its 'good work' (Transition Monitoring Group, 2007; Ibrahim, 2007).

Running counter to this notion of democracy was the version upheld by Obasanjo's opponents: it was linked to the preservation of 
institutions and populist economic policies. By this understanding of democracy, respecting constitutional limits to terms of office was a necessary part of the democratic process in a country where crises of political succession have remained endemic. Consequently, contesting the extension of the presidential term of office became part of the larger struggle against Obasanjo's policies of public expenditure cuts (especially in health and education); massive retrenchment in the public services; constant increases in the price of petroleum products; and privatization of public enterprises. Throughout the eight years of Obasanjo's presidency, civil society and labour groups organized strikes and public demonstrations against the steady rise in petroleum prices and the economic hardship. In short, many Nigerians had a concept of democracy that was diametrically opposed to that of Obasanjo and his team. Our study shows that, for many, the removal of the Obasanjo regime became a sine qua non for the possibility of deepening democracy.

\section{Nigeria's political economy and the political context}

Nigeria has an estimated population of 140 million, and is a federal democracy consisting of thirty-six states and a federal capital territory, further subdivided into 774 local governments. Prolonged military rule (for thirty out of the fifty years since independence) has had a considerable effect on party democracy and elections, eroding constitutional federalism through massive centralization of power and resources, violating the rights of citizens, rubbing away at the rule of law, and enshrining a culture of arbitrariness and impunity that has resulted in high levels of corruption. Military rule ended in 1999, and the return to democracy under the Fourth Republic was heralded by a new constitution. Obasanjo was the first president of this new era.

Nigeria's population comprises over 375 ethnic groups (Otite, 1990), almost equally split between Muslims and Christians; it has a literacy rate of less than 60 per cent. Although not constitutionally entrenched, the existing six geopolitical zones are well recognized as the basis for sharing power and promoting equity among the component parts of the federation. ${ }^{3}$ Nigeria's plural and diverse ethnic, regional and religious character provides a key defining context for its electoral democracy. The ethnic groups that live in Nigeria vary in size, history and influence, and the tendency for the political elite to politicize and exploit these identities has led to an intense competition for state power and publicly controlled resources.

The politicization of ethnic and sectional identity has responded 
dynamically to the changing character of federal politics and the shifting context of the struggle for power and resources. For instance, from the late colonial period to the end of the First Republic in 1966, 'politics of difference' played the three regions of the day - east, north and west - off against each other (each region coinciding with the interests of one of the three largest Nigerian ethnic groups). However, the feeling of oppression expressed by the ethnic minorities within these regions generated considerable social tension towards the end of colonial rule, and this survived into the post-independence era as demands for the creation of new states and local governments in the new Nigeria.

A dominant feature of contemporary Nigerian politics remains the major role played by ethno-regional political organizations. Key expressions of ethnic and regional platforms today include the Arewa Consultative Forum (ACF) (representing the core north, which is, rather simplistically, identified as Hausa-Fulani), the Afenifere (the platform of the Yoruba-speaking population of the south-west) and the Ohaneze N'digbo (advancing the interests of the Ibo-speaking population in the south-east). There are other ethno-regional organizations that represent the various ethnic minorities, and these are useful in the mobilization of communal identity for electoral purposes. Against this background, and despite an increased liberalization of the political space, Nigerian political parties have remained fragile; their institutional weakness is a central challenge in establishing a healthy electoral democracy. ${ }^{4}$ The main reason for this weakness is the predominance of a core of practitioners within the political class: they came to the fore under successive military regimes, when there was an absence of internal democracy within party organizations and during a long period of decline in ideology- and issuesbased politics in parties and campaigns. The political parties are also weak in terms of democratic accountability, being answerable neither to their members nor to the Nigerian populace (despite the fact that they are publicly funded).

The postcolonial path to economic development - and the role of the state within it - was heavily influenced by the colonial model. It was essentially defined by the following: a state-led approach to capitalist modernization; a dependent strategy, which emphasized a significant role for foreign capital; an import-substitution industrialization strategy; and a philosophy of development that excluded most ordinary people from meaningful participation in the development process.

The emergence of the petroleum economy in the 1970s, however, is what has had the most significant impact on the Nigerian political economy. Between 1960 and 1964, agriculture accounted for 79 